\title{
Factors Influencing The Financial Independence of Young Adults, and Evidence From Indonesia
}

\author{
Evelyn $^{1 *}$, Ricky ${ }^{2}$, Sherly Rosalina Tanoto ${ }^{3}$ \\ ${ }^{1,2,3}$ Faculty of Business and Economics, Petra Christian University \\ Jl Siwalankerto 121-131, Surabaya 60236, Indonesia \\ *Corresponding author; Email: evelyn@ petra.ac.id
}

\begin{abstract}
Financial independence is a mark of an individual's maturity. Achieving financial independence for an individual is very important for family life. Society would be better off when most of its members were independent financially. This study investigates whether different groups of young adults based on their age, gender, education, and income significantly differ in their financial independence. Also, this research intends to study demographic factors that influence the financial independence of a society. The research method was quantitative by using a survey with 539 respondents. The result shows that different groups of young adults categorized based on age, gender, education, and income have a significant difference related to financial independence. Age and income are the two most important factors influencing the financial independence of young adults.
\end{abstract}

Keywords: Financial Independence; Demographic Factors; Young Adults; Indonesia.

\section{Introduction}

One of the indicators that an individual has grown into adulthood is their financial independence (Fingerman et al., 2012; Melgar \& Rossi, 2012; Xiao, Chatterjee \& Kim, 2014; Bea \& Yi, 2017; Pappang and Anastasia, 2019). Financial independence is a condition where individuals can meet their needs with their earnings (Carpenter \& Moore, 2008). In other words, independent people are the ones who can earn income or have assets that they can use to meet their needs, and thus, their financial matters are separated from their parents or guardians (Xiao, Chaterjee \& Kim, 2014).

Ideally, an individual's financial independence happens when their age is between 18-24 years old (Newman \& Newman, 2012). However, recent studies have shown that the transition towards maturity has been shifted to longer age than previously mentioned (Xiao et al., 2014; Harrison, Marchant \& Ansell, 2016). Further studies suggest that the shift happens all over the world (Sironi \& Furstenburg, 2012; Friedline \& Rautkis, 2014; Fingerman et al., 2015; Bea \& Yi, 2017).

The higher education degree that young adults must achieve is among the main factors that increase the financial dependence of these youngsters on their parents (Naafs, 2012; Bea \& Yi, 2017). However, education is not the only reason young adults have yet to achieve financial independence. Young people already working are often still financially dependent on their parents (Friedline \& Rautkis, 2014; Fingerman et al., 2015). In addition, increasingly difficult economic conditions, increasing uncertainty in employment, and rising prices of necessities have made the income earned by young people not commensurate with their expenses (Bea \& Yi, 2017). These issues prolong a person's financial dependence on his parents.

The transitional period towards financial independence is a crucial time in an individual's life. When a young adult is not financially independent, s/he will receive a negative perception from their surroundings. Furthermore, this negative perception will lead to adverse treatment where not economically independent young adults might be marginalized by society (Naafs, 2012). Another alarming reality is that those young adults are forced to work during school to get their 'financial independence'.

These young adults gained their current financial independence at the expense of their college education. This might threaten the sustainability of their financial freedom due to the future competition in the workforce (Xiao, Chatterjee, and Kim, 2014). Young adults who did not get enough support from their parents or family during their growth into adulthood have the potential of being trapped into indebtedness or forced to pay their debts after they get their first job (Mortimer, 2012). The transitional period towards adulthood is crucial since it is the time for 
young adults to finish their education and start their careers (Cacciattolo, 2015).

Financial independence is an essential and interesting topic to be researched. Xiao et al. (2014) suggest that the economic independence of young adults needs to be compared between nations to ensure that relevant parties such as policymakers, parents, and schools could help the young adults go through their transitional period very well. However, research about financial independence is still not much (Sironi \& Furstenburg, 2012; Xiao et al., 2014; Bea \& Yi, 2018). This is even more limited in the context of Indonesia. Therefore, this research is aimed to study the financial independence of young adults in Indonesia. First, the study is expected to describe the level of financial independence of young adults in Indonesia. Secondly, this research is expected to compare the financial independence between different young adults in Indonesia. Last but not least, this study wants to investigate the impact of demographic characteristics on the financial independence of young adults of Indonesia. The researchers expect that their research will give a clearer picture of the financial independence of young adults so that these people can be guided towards their financial independence.

\section{Literature Review}

\subsection{Financial Independence}

Whittington and Peters (1996) describe that people are independent financially when they live away from their parents and can independently fulfill their financial needs. Lee \& Mortimer (2009), and Xiao et al. (2014) measure financial independence as the degree by which individuals pay their bills or, in other words, to what extent others, such as parents or spouses, pay their bills.

One of the methods that have been used to study financial independence is the Panel Study of Income Dynamics-Transition into Adulthood Supplement (PSID-TAS). PSID-TAS classifies financial independence into four levels (Xiao et al., 2014; Bea \& Yi, 2017).

Xiao et al. (2014) and Bea and Yi (2017) explain that the first level means that the individual is independent enough to pay for their daily needs such as food, transportation, and other everyday essentials. At the same time, the second level means that the person is financially sufficient to pay for their accommodation costs such as rent and mortgage. The third level means that the individuals can pay on their own their consump- tive expenses such as credit cards, car credit dues, and debt instalments (other than the ones for accommodation and working capital). Finally, the last category explains people who manage their finances and are not just barely able to pay their dues and bills (Xiao et al., 2014; Bea \& Yi, 2017). These four levels, with their indicators, explain that financial independence is about financial stability that has a lot to do with one's ability to obtain sufficient income and manage it (Marsh, 2006).

Table 1. Four Levels of Financial Independence (PSID-TAS)

\begin{tabular}{cl}
\hline Level & \multicolumn{1}{c}{ Indicator of financial independence } \\
\hline 1 & $\begin{array}{l}\text { Paying for food, transportation, and other daily } \\
\text { needs on their own. } \\
\text { They are paying for the rent or mortgage } \\
\text { associated with their accommodation. } \\
\text { They are paying for their consumptive expenses } \\
\text { such as credit cards, vehicles, and other debts. } \\
\text { They are managing their finances, including } \\
\text { earning management and earning allocation. }\end{array}$ \\
\hline
\end{tabular}

Achieving financial independence is very important for young adults. This will influence how they view themselves; they perform their role in their family and contribute to society (Lee \& Mortimer, 2009). Financial independence has been correlated to the self-confidence of individuals, and this is also true for young adults. Young adults view their financial independence as their ability to be responsible with their own lives (Shim et al., 2009). For Schleicher (2013), this sense of responsibility will influence the other aspects of their lives. Parents who have children at their young adult age that financial independence will give these parents a sense of relief, thus enabling them to focus on their financial planning such as retirement plan (Xiao et al. 2014). Financial independence of the young adults as part of the overall independence will give the society a sense of economic strength as every member of the society is productive enough to meet their needs on their own.

\subsection{Young Adults and Financial Independence}

Scholars of anthropology divide the life cycle of human beings into several stages. Hurlock (1978) divides the human life cycle into prenatal, natal, baby, child, teen and young adult. In the latter study, Hurlock (2017) detailed the young adult into an early young adult (age 18-40 years old, mid young adult (40-60 years old) and senior young adult (more than 60 years old). Another scholar, Erikson (1968 in Santrock, 2017), divides 
one's adulthood into adolescence $(13-19$ years old), early adulthood ( $20-39$ years old, middle adulthood (40 - 59 years old), and late adulthood (> 60 years old). Newman \& Newman (2012) have their division where early adolescence (12 to 18 years), later adolescence ( 18 to 24 years olds), early adulthood (24 to 34 years old, Middle Adulthood (34 to 60 years old), Later adulthood (60 to 75 years old), dan Elderhood (75 Until Death). Arnett (in Butterbaugh, Ross and Campbell, 2020), who developed Erikson's idea, suggested a term called 'emerging adulthood' (age 18-25 years old).

Despite their different cut-offs in categorizing adulthood, scholars previously mentioned agreeing that individuals will experience what sense of looking for direction in their transition from teenage to young adult, which for Erikson (in Santrock, 2017) is called 'identity role confusion' or Arnett (in Butterbaugh, Ross \& Campbell, 2020) feeling in between. In this period, teenagers will try their best to appear ready to go into their adulthood. However, on the other hand, these teenagers seem to be unable to leave the comfort of the teenage years and thus are not prepared to be an adult.

Different scholars mark adulthood differently. Xiao et al. (2014) suggest that the generally accepted indicators of maturity for people are their financial independence, that they have graduated, and can support their own family. Arnett (in Butterbaugh, Ross \& Campbell, 2020) argues that the most crucial mark of adulthood of individuals is the quality of their character. People will be considered an adult when they can meet their own needs independently, including being responsible for their own lives, making their own decisions and meeting their financial markets on their own. Butterbaugh, Ross and Campbell (2020) stress that financial independence is a significant mark that one has entered the early part of their adulthood. This means the individual has reached confident readiness for leaving their family to start one of their own (Naafs, 2012). One of the teenagers' anxieties to move to adulthood is the financial consequences. On the one hand, these teenagers felt responsible for reaching financial independence. However, on the other hand, they are still not ready to meet their needs on their own and thus still depend on their parents financially.

\subsection{Factors That Influence Financial Independence}

Scholars have different views on the factors influencing an individual's financial independence. Factors commonly correlated to financial independence are age, marital status, education and income level. Smith, Baum \& McPherson (2008) suggest that the responsibility of parents on their children should end when their children have reached 22 years old when they have finished their bachelor study. However, Bea \& Yi (2017) argue that financial independence is not necessarily correlated with age. The family's condition where they were born might have something to do with it. People who grew up in an unfortunate family will be forced to be independent financially at such a young age (Lyons, 2004). On the contrary, being born into a fortunate family will make sure people keep receiving supports from their parents and thus make them financially independent in a longer time (Swartz et al., 2011; Johnson \& Benson, 2012; Fingerman et al., 2015; Pappang and Anastasia, 2019).

Gender wise, there is a difference in becoming mature and independent between men and women. Men are considered separate, individualistic, and goal-oriented, while women are regarded as less independent, depending on their community and has no orientation on their own (Hurlock, 2017). However, Cuddy et al. (2015) investigated the relationship among gender, culture, and independence, arguing that the cultural context influences the previous stereotyping. For example, in western culture, men are considered more independent than men; however, women are considered more independent and stronger than men in eastern culture.

Studies by Carpenter \& Moore (2008), and Lee \& Mortimer (2009) suggest that males are more independent and confident financially compared to females. However, Sironi \& Furstenburg (2012) argue that females will be more independent due to the gender equality movement and the rise of financial needs in society that require both genders to earn more. Females are no longer dependent on their spouse or family, but they make more than males.

Sage \& Johnson (2012), and Johnson (2013) stated that the financial assistance provided by parents to their children would decrease when the children are married. Marital status will signal 
(both to yourself and others, including parents). Therefore, normatively, a person is expected to be financially independent before marriage. Financial support by parents to their children will be decreased when their children have already acquired the marital status as the mark that these children have reached adulthood. The globally accepted norm suggests that financial independence should be obtained before married life.

Xiao et al. (2014) suggest that income influences an individual's financial independence because a decent income will guarantee their ability to live a content life. It is publicly accepted that different people have a different standard of living and that people with higher income will tend to be independent financially. The level of education has been known as a factor influencing the independence of individuals. However, in the particular educational funding system, for the ordinary people, those with a higher level of education tend to be financially dependent on their guardians for a very long time. This is simply because, on top of the expensive education cost, the longer people studied, the lower their chance of working and gaining financial independence. Therefore, young adults still pursuing their education tend to depend on their parents. However, once they graduate, they have a better chance of earning more than their peers who did not go through a higher level of education (Sironi \& Furstenburg, 2012; Johnson, 2013; Xiao et al., 2014; Bea \& Yi, 2017).

\subsection{Financial Independence in Indonesia}

Minza (2014) argues that Indonesians are convinced that youngsters reach adulthood when they can fulfil their needs on their own without getting any help from others. Indonesians also consider that the majority level will be higher when young adults can support their family, both their current or future family. Therefore, maturity in Indonesia could be categorized based on the amount of contribution Indonesian young adults make to their families.

Lai (2011) argues that people's average age of financial independence will be different in different countries. Generally, the range of age of people reaching their financial independence is between 23-25 years old. In Indonesia, however, the average age is 27 years old. One of the reasons is that Indonesians tend to have a higher consumption rate than their income. Scholars also argue that Indonesians tend to feel complacent with the rich natural resources and the pampering parenting from their parents. Therefore, they want their children to have a good life by supporting their parents financially.

Furthermore, Lai (2011) also explains that young adults in Indonesia tend to be older when reaching maturity because many have not got a steady job. Bowo (2013) argues that many young adults in Indonesia are reluctant to become entrepreneurs and thus unable to earn a sufficient income. Many youngsters in Indonesia tend to work for others whose salary is insufficient to support their lives.

A study by Kusumawati \& Kristiana (2017) suggests that Indonesians view women's main job as housewives or mothers. Thus, having a career in an organization would be considered a secondary task. This means that Indonesian society demands men to be more independent financially. However, Himawan, Bambing, \& Edirippulige (2018) argue that 'modern' Indonesian women are more independent, have a high-level career, and thus, high-paying jobs. Furthermore, the scholars also suggest that certain independent Indonesian women consciously decided to remain single. Again, Nobles \& Buttenheims (2008) indicate that married Indonesian women are more financially independent than peers from other Asian countries.

Jones (2010) describes that it is common for Indonesian married couples to still stay in their parent's house before eventually living on their own. Oliveira (2016) states that the norm where the married couples remained in their parents' house for Indonesian is part of generational wealth transfer. Indonesians are fighting to support their children with a high enough educational degree to bring family pride in the eyes of society parents (Naafs, 2012; Minza, 2014). On top of the pride, a higher academic degree is expected to lead to a high-paying job that will enable the will of their parents and lift their family's social and economic status (Naafs, 2012; Minza, 2014).

Frankenberg et al. (2002) point out an interesting phenomenon: many Indonesian young men keep receiving financial support from their parents. This happens simply because one of the couples works and the other does not, and a single income is barely enough to support the family spending. Naafs (2012) adds that this happens simply because jobs are unavailable for every college degree graduate in Indonesia. 


\subsection{Hypotheses}

Based on the research purpose of knowing whether different demographic factors influence financial independence, the researchers set two hypotheses. First, the papers propose that the financial independence of youngsters could be differentiated across the demographic factors and that these demographic factors are influencing financial independence. These propositions lead the researchers to pose two hypotheses:

$\mathrm{H}_{1}$ : The financial independence of the youngsters in Indonesia are significantly different when financial freedom is being compared in terms of age, gender, marital status, income and level of education.

$\mathrm{H}_{2}$ : Demographic characteristics, namely age, gender, marital status, income and level of education, influence the financial independence of the young adults of Indonesia.

\section{Methods}

\subsection{Sampling}

This research uses a survey as its methodology. The survey is being done by spreading questionnaires to respondents between $18-40$ years old. The 18 years old 'floor' is used following Hurlock's (2017) suggestion that 18 is the minimum age to be measured for financial independence. The distribution of the question is being done using an online method employing google platform with the help of open survey platform 'Jakpat'. Out of more than 600 questionnaires, 539 returned questionnaires are eligible to be processed. The sampling method uses simple random sampling targeting young adults in 33 provinces. However, unfortunately, the respondents came from 18 significant provinces in Indonesia, so it is expected to give an idea of financial independence from young adults in Indonesia. In addition, relevant literature and statistical data from the Statistical Bureau of Indonesia are being used to discuss the result or findings.

\subsection{Measurements}

This research defines financial independence as a condition where an individual could meet their needs without having support from others. This independence is measured based on the TAS (Transition into Adulthood Supplement) indicator points 1,2 , and 4 . Point 3 of the indicator is not being used because most respondents don't have a wasteful loan. Questions related to financial independence is a Likert scale where $1=$ entirely dependent financially and $5=$ fully independent financially.

\subsection{Data Analysis}

The first research question will be answered using descriptive analysis and cross-tabulation analysis for every variable. Considering the type and characteristics of the data in this research, the comparison process of the financial independence between groups will be done using the KruskallWallis test because the data in this study cannot meet the assumption of normality and dependent variables consist of more than two groups. The overall financial independence will be tested using the post hoc test using the Mann Whitney $\mathrm{U}$ test. Lastly, to analyze the influence of the demographic characteristics on the financial independence of the young adult of Indonesia, the researchers use logistic binomial regression. Tolles \& Meurer (2016) suggest that logistic binomial regression is suitable for knowing whether one out of two options taken by respondents is affected by the independent variables. In this research, the two options are entirely financial independence and ultimately not financial independence.

\section{Results}

Descriptive statistics of the research can be seen in Table 1. The average age of the respondent is 25 years old. Most of the respondents (76.809\%) are still single, and $72.913 \%$ have a Diploma or Bachelor for their level of education. The finding also shows that the majority of the respondents earned IDR 4.2 million until IDR 10 million. The lowest level, 4.2 million, is being used as the minimum Regional Wage set by the Minister of Labor in Indonesia. Many respondents who reported earning less than IDR 4.2 million still have student status, thus receiving the allowance from their parents.

The researchers used three categories in categorizing financial independence: 'daily needs', 'accommodation', and 'financial management (Xiao et al., 2014). 'Daily needs' means the young adults can only cover their daily needs such as food, transportation and other daily needs. In contrast, 'accommodation' means that the young adults can cover the accommodation that enables them to live outside their parents' house (Xiao et al., 2014). The respondents are complete- 
Table 2. Descriptive Statistics of the Research

\begin{tabular}{|c|c|c|c|c|c|c|c|c|c|}
\hline & \multirow{3}{*}{$\begin{array}{c}\text { Percentage of } \\
\text { Total } \\
\text { Respondent }\end{array}$} & \multicolumn{8}{|c|}{ Crosstab } \\
\hline & & \multicolumn{2}{|c|}{ Daily Needs } & \multicolumn{2}{|c|}{ Accommodation } & \multicolumn{2}{|c|}{ Financial Management } & \multicolumn{2}{|c|}{ Financial Independence } \\
\hline & & Dependent & Independent & Dependent & Independent & Dependent & Independent & $\begin{array}{l}\text { Dependent } \\
\end{array}$ & Independent \\
\hline \multicolumn{10}{|l|}{ Age } \\
\hline Age 18-24 & $52.690 \%$ & $28.76 \%$ & $23.93 \%$ & $43.78 \%$ & $8.91 \%$ & $12.99 \%$ & $39.70 \%$ & $29.87 \%$ & $22.82 \%$ \\
\hline Age 25-29 & $21.707 \%$ & $4.45 \%$ & $17.25 \%$ & $13.17 \%$ & $8.53 \%$ & $2.41 \%$ & $19.29 \%$ & $4.64 \%$ & $17.07 \%$ \\
\hline Age 30-34 & $14.100 \%$ & $2.41 \%$ & $11.69 \%$ & $4.27 \%$ & $9.83 \%$ & $1.67 \%$ & $12.43 \%$ & $2.23 \%$ & $11.86 \%$ \\
\hline Age $35-40$ & $11.503 \%$ & $0.56 \%$ & $10.95 \%$ & $1.30 \%$ & $10.20 \%$ & $1.30 \%$ & $10.20 \%$ & $0.74 \%$ & $10.76 \%$ \\
\hline \multicolumn{10}{|l|}{ Gender } \\
\hline Women & $42.486 \%$ & $17.81 \%$ & $24.68 \%$ & $28.76 \%$ & $13.73 \%$ & $7.98 \%$ & $34.51 \%$ & $18.00 \%$ & $24.49 \%$ \\
\hline Men & $57.514 \%$ & $18.37 \%$ & $39.15 \%$ & $33.77 \%$ & $23.75 \%$ & $10.39 \%$ & $47.12 \%$ & $19.48 \%$ & $38.03 \%$ \\
\hline \multicolumn{10}{|l|}{ Marital Status } \\
\hline Not Married & $76.809 \%$ & $34.14 \%$ & $42.67 \%$ & $57.70 \%$ & $19.11 \%$ & $14.66 \%$ & $62.15 \%$ & $35.25 \%$ & $41.56 \%$ \\
\hline Married, No Children & $2.968 \%$ & $0.00 \%$ & $2.97 \%$ & $0.93 \%$ & $2.04 \%$ & $0.37 \%$ & $2.60 \%$ & $0.00 \%$ & $2.97 \%$ \\
\hline Married, Have Children & $20.223 \%$ & $2.04 \%$ & $18.18 \%$ & $3.90 \%$ & $16.33 \%$ & $3.34 \%$ & $16.88 \%$ & $2.23 \%$ & $18.00 \%$ \\
\hline \multicolumn{10}{|l|}{ Income } \\
\hline$<$ IDR $4,200,000$ & $40.260 \%$ & $23.93 \%$ & $16.33 \%$ & $29.68 \%$ & $10.58 \%$ & $11.69 \%$ & $28.57 \%$ & $24.12 \%$ & $16.14 \%$ \\
\hline IDR $4,200,000$-IDR $10,000,000$ & $47.866 \%$ & $11.13 \%$ & $36.73 \%$ & $28.76 \%$ & $19.11 \%$ & $5.94 \%$ & $41.93 \%$ & $12.06 \%$ & $35.81 \%$ \\
\hline$>$ IDR $10,000,000$ & $11.874 \%$ & $1.11 \%$ & $10.76 \%$ & $4.08 \%$ & $7.79 \%$ & $0.74 \%$ & $11.13 \%$ & $1.30 \%$ & $10.58 \%$ \\
\hline \multicolumn{10}{|l|}{ Education } \\
\hline Senior High School & $19.852 \%$ & $5.01 \%$ & $14.84 \%$ & $8.72 \%$ & $11.13 \%$ & $3.90 \%$ & $15.96 \%$ & $4.82 \%$ & $15.03 \%$ \\
\hline Bachelor & $72.913 \%$ & $29.31 \%$ & $43.60 \%$ & $50.09 \%$ & $22.82 \%$ & $13.73 \%$ & $59.18 \%$ & $31.17 \%$ & $41.74 \%$ \\
\hline Master and Doctorate & $7.236 \%$ & $1.86 \%$ & $5.38 \%$ & $3.71 \%$ & $3.53 \%$ & $0.74 \%$ & $6.49 \%$ & $1.48 \%$ & $5.75 \%$ \\
\hline \multirow{2}{*}{\multicolumn{10}{|c|}{$\begin{array}{l}\text { Financial Independence } \\
\text { Daily Needs }\end{array}$}} \\
\hline & & & & & & & & & \\
\hline Completely Dependent & $13.915 \%$ & & & $13.36 \%$ & $0.56 \%$ & $4.82 \%$ & $9.09 \%$ & & \\
\hline$>50 \%$ & $15.399 \%$ & & & $14.84 \%$ & $0.56 \%$ & $6.31 \%$ & $9.09 \%$ & & \\
\hline $50 \%$ & $6.865 \%$ & & & $6.31 \%$ & $0.56 \%$ & $1.48 \%$ & $5.38 \%$ & & \\
\hline$<50 \%$ & $14.471 \%$ & & & $10.95 \%$ & $3.53 \%$ & $1.86 \%$ & $12.62 \%$ & & \\
\hline Completely Independent & $49.351 \%$ & & & $17.07 \%$ & $32.28 \%$ & $3.90 \%$ & $45.45 \%$ & & \\
\hline \multicolumn{10}{|l|}{ Accommodation } \\
\hline Completely Dependent & $49.722 \%$ & $24.86 \%$ & $24.86 \%$ & & & $8.91 \%$ & $40.82 \%$ & & \\
\hline$>50 \%$ & $7.421 \%$ & $6.49 \%$ & $0.93 \%$ & & & $3.53 \%$ & $3.90 \%$ & & \\
\hline $50 \%$ & $5.380 \%$ & $3.15 \%$ & $2.23 \%$ & & & $1.67 \%$ & $3.71 \%$ & & \\
\hline$<50 \%$ & $5.380 \%$ & $1.11 \%$ & $4.27 \%$ & & & $1.11 \%$ & $4.27 \%$ & & \\
\hline \multirow{2}{*}{\multicolumn{10}{|c|}{ Financial Management }} \\
\hline & & & & & & & & & \\
\hline Completely Dependent & $5.195 \%$ & $3.71 \%$ & $1.48 \%$ & $4.08 \%$ & $1.11 \%$ & & & & \\
\hline$>50 \%$ & $7.050 \%$ & $5.75 \%$ & $1.30 \%$ & $5.38 \%$ & $1.67 \%$ & & & & \\
\hline $50 \%$ & $6.122 \%$ & $3.15 \%$ & $2.97 \%$ & $4.64 \%$ & $1.48 \%$ & & & & \\
\hline$<50 \%$ & $7.607 \%$ & $3.15 \%$ & $4.45 \%$ & $5.57 \%$ & $2.04 \%$ & & & & \\
\hline Completely Independent & $74.026 \%$ & $20.41 \%$ & $53.62 \%$ & $42.86 \%$ & $31.17 \%$ & & & & \\
\hline \multicolumn{10}{|l|}{ Financial Independence } \\
\hline Completely Dependent & $37.477 \%$ & & & & & & & & \\
\hline Completely Independent & $62.523 \%$ & & & & & & & & \\
\hline
\end{tabular}

ly dependent when their parents provide more than $50 \%$ of their daily spending, while completely independent means less than $50 \%$. This goes as well for the accommodation category where completely dependent is for those whose parents cover more than $50 \%$ of accommodation costs. Completely independent is for those whose parents cover less than $50 \%$ of their accommodation costs. 'Financial management for Xiao et al. (2014) means that the young adults are managing their finances and not just being able to cover their expenses. Completely dependent is for those whose parents manage more than $50 \%$ of their financial issues. Thus, completely independent is for those whose parents manage less than $50 \%$ of their financial matters.

This research uses the code 'dependent' to group respondents who are not financially independent, while 'independent' is for those who have reached financial independence. To be categorized as financially independent (FI), the researchers use Maholtra's (2019) average calculation where the average score for 'daily', 'accommodation' and 'financial management' score of 1-3 will be categorized as a dependent (coded 0/zero) and the average score of more than 3-5 will be classified as independent (coded as $1 /$ one).
From the three questions on financial independence, most respondents claimed that they could manage their financial matters $(74.026 \%)$. However, $5.195 \%$ said that others do their financial management out of all respondents. The second-highest level of financial independence is the ability of the income to fulfil daily needs. Almost half of the respondents (49.351\%) claimed that they could fulfil their needs using their pay. On the other hand, $13.915 \%$ stated that their income could not meet their daily needs. Furthermore, $36.735 \%$ said they could meet only a part of their needs using their income while other parties covered the shortage.

The finding also shows that the most challenging level of financial independence is meeting the accommodation cost as they have decided to live outside their parents' house. This means they find it difficult to pay for the house or room rent, let alone buy their own house using their own money. Almost half of the respondents $(49.722 \%)$ stated that they relied on others (mainly parents) for covering their accommodation cost, and only $32.096 \%$ said they are' independent' enough to cover it themselves.

Overall, more than half of the respondents $(62.523 \%)$ can be categorized as financially independent. However, on the contrary, $37.477 \%$ 
Table 3. Results of the Kruskal Wallis test

\begin{tabular}{|c|c|c|c|c|c|c|c|c|}
\hline & \multicolumn{2}{|c|}{ Daily Needs } & \multicolumn{2}{|c|}{ Accommodation } & \multicolumn{2}{|c|}{ Financial Management } & \multicolumn{2}{|c|}{$\begin{array}{c}\text { Financial } \\
\text { Independence }\end{array}$} \\
\hline & Sig & & Sig & & Sig & & Sig & \\
\hline Age & 0.000 & $* * *$ & 0.000 & $* * *$ & 0.001 & $* * *$ & 0.000 & $* * *$ \\
\hline Gender & 0.017 & $* *$ & 0.033 & $* *$ & 0.833 & & 0.044 & $* *$ \\
\hline Marital Status & 0.185 & & 0.272 & & 0.684 & & 0.164 & \\
\hline Income & 0.014 & $* *$ & 0.000 & $* * *$ & 0.163 & & 0.014 & $* *$ \\
\hline Education & 0.076 & $*$ & 0.027 & $* *$ & 0.185 & & 0.007 & $* * *$ \\
\hline
\end{tabular}

Table 4. Results of Logistic Regression

\begin{tabular}{|c|c|c|c|c|c|c|c|c|c|c|c|c|}
\hline & \multicolumn{3}{|c|}{ Daily Needs } & \multicolumn{3}{|c|}{ Accommodation } & \multicolumn{3}{|c|}{ Financial Management } & \multicolumn{3}{|c|}{ Financial Independence } \\
\hline & $\beta$ & Sig & & $\beta$ & Sig & & $\beta$ & Sig & & $\beta$ & Sig & \\
\hline Age & 0.717 & 0.000 & $* * *$ & 0.891 & 0.000 & $* * *$ & 0.519 & 0.004 & $* *$ & 0.772 & 0.000 & $* * *$ \\
\hline Income & 1.294 & 0.000 & $* * *$ & 0.362 & 0.042 & $* *$ & 0.909 & 0.000 & $* * *$ & 1.183 & 0.000 & $* * *$ \\
\hline Education & -0.369 & 0.112 & & -0.419 & 0.055 & $*$ & -0.016 & 0.948 & & -0.352 & 0.123 & \\
\hline Percentage Correct & & 76.3 & & & 77.7 & & & & & & & \\
\hline Nagelkerke R Square & & 0.347 & & & 0.397 & & & & & & & \\
\hline
\end{tabular}

of them are classified as not independent financially as they still could not cover their needs and their financial matters.

Table 3 shows a significant difference in the respondents' financial independence as it is being compared based on their age, gender, marital status, income and level of education. This is also true regarding spending for accommodation and their overall financial independence. However, in terms of financial management, the significant difference only happens when that level of independence among respondents is being compared in terms of their age.

The result of the crosstab in Table 2 shows that the older the age of the respondents, the higher their level of financial independence. The finding also indicates that the financial independence of men is significantly higher than women. This means men are more capable of paying their daily needs and accommodation costs. This finding of this research is also consistent with the theory that says that the higher the income of the people, the higher their level of independence. Surprisingly, the level of financial independence of respondents who have a high school education is higher than those who have got their Master and Doctorate levels. This is so true related to their ability to pay for the accommodation cost.

The next step of the post hoc test on the overall financial independence shows a signifi- cant difference in financial independence of respondents falling into age 18-24 compared to those of other age categories. Furthermore, there is a significant difference among groups categorized based on income. In terms of the level of income, the test shows a significant difference between those who have obtained a Diploma and Bachelor level of education compared to those of another education level.

Table 4 shows the result of the logistic regression result. The logistic regressions are done four times with four dependent variables: daily needs, accommodation, financial management and financial independence. The data processing method shows that the financial independence of people in terms of meeting their daily needs, paying for their accommodation cost, financial management and overall financial independence is influenced by their age and income. Marital status has no impact on the dependent variable because parents have the norm that they do not want to see their children suffer through their financial independence journey. However, the crosstabs result shows otherwise because a portion of the parents might hold to other norms where they are not afraid of 'losing face' because of the struggle of their children to reach their financial independence status (Xiao et al., 2014). The level of education influences only the financial independence of individuals in terms of the ability to pay for accommodation needs. 


\section{Discussion}

\subsection{Summary of the Findings}

The research shows that the majority of the young adults in Indonesia are still on their way towards financial independence or that they are not yet reaching a total sense of financial freedom. The average age at this age is 25 years old, and on average, Indonesians at that age just finished their Bachelor degree not, and many of them are still studying at their Masters level. Moreover, the ones that are still learning usually are still being supported by their parents.

The second factor is occupation or job. Bowo (2013) suggests that the majority of the urban Indonesians work as employees or staff. However, at the age of 25 usually are still in the early years of their professional career. Thus, their income is barely enough to cover their living expenses in a big city. This is even worse for those who have graduated from college who, for Naafs (2012), are still unable to find their routine jobs. This concludes that their position at such an early age does not guarantee them to earn the entire meaning of financial independence.

The third accommodation factor hinders young adults in Indonesia from reaching their financial independence. The high price of houses or apartments caused many young adults who had just started their careers not to afford their accommodation. Many of them who could usually are still being supported by their parents. Jones (2010) explains that many young couples who have been married for so many years are forced to live with their parents, and this, for Furstenburg (2012), indeed does not encourage them to reach their financial independence.

This research finds that two demographic factors strongly influence the financial independence of young adults in Indonesia, namely age and income. These findings are in line with the studies done by Whittington \& Peters (1996), Smith et al. (2008), and Xiao et al. (2014). Age strongly influences financial independence because their parents still support them and most likely do not want to lose face due to their children's financial struggles. Furthermore, Burcher et al. (2018) suggest that these young adults are still trying to establish their jobs or businesses at their early stage of careers. Therefore, it is pretty apparent that their income at the early stage of their professional career is still inadequate. Therefore, the older they are, the more they are financially independent.
This research finds that the crosstab shows gender is a significant differentiator of financial independence. However, the logistic results show otherwise, which means parents support their children regardless of gender. These parents do not want their children to be underestimated by their peers, who most likely will determine the future marital status of their children (Lai, 2017). Furthermore, on gender, males are more independent financially than females. However, females are more tidy and meticulous in managing personal finance than males. Female young adults in Indonesia, are getting more and more recognition to be treated equally with the males. This, for Himawan et al. (2018), means that these females are getting what they deserve based on their capacity and not their gender.

\subsection{Implications}

This research is expected to provide academic and practical insight. The valuable insight is primarily for the young adults where they are expected to increase their competencies to earn a 'higher income' to increase their chance to reach financial independence. Increasing their competencies means these young adults should study harder, make valuable connections, sharpen their skills and become trustworthy individuals. These things are believed to be the ingredients to produce quality work, eventually bringing higher income.

The result of the research also shows that financial independence is difficult to be achieved by young adults in Indonesia due to their difficulties to afford the cost of their accommodation. The implication for this is that the government should consider allocating specific budgets to support the aspiration of young adults, especially the young couple, to own their accommodation. This governmental aid will encourage these young adults to set aside balanced funds from their income to buy their first house or apartment.

An interesting finding of this research is that education does not influence individuals' financial independence, especially how they manage their finances. This is because the level of education of these young adults does not necessarily match their expected job, thus the expected salary. The other important implication is that the policymakers in education need to be aware that financial management skills have not been transferred to these young adults as they are growing up. This means the young adults in 
Indonesia need to ensure that their level of education reflects their skills and that they are equipped with the personal financial management skills to manage what they earn.

\section{Conclusions}

Despite the essential findings and their implications, this research can be considered an early stage of researching the financial independence of young adults in Indonesia. This research could develop many aspects, such as the psychological elements influencing an individual's financial independence (Xiao et al., 2014). Investigating the roles of the parents can be very interesting since many 'assumptions' related to finance have been instilled in young adults since they were very young. These might influence their attitude towards saving, investment and doing entrepreneurial activities. More research on this topic will enrich relevant stakeholders on the issues surrounding financial independence among young adults. These stakeholders, along with the young adults themselves, will be assisted in making evidence-based policy and planning.

\section{References}

Bea, M. D., \& Yi, Y. (2017, January). Variation in Young Adults' Transitions to Financial Independence and Implications for Financial Security [Paper presentation]. PAA 2017 Annual Meeting Submission, Chicago, Illinois.

Bea, M. D., \& Yi, Y. (2018). Leaving the Financial Nest: Connecting Young Adults' Financial Independence to Financial Security. Journal of Marriage and Family, 81(2), 397414. https://doi.org/10.1111/jomf.12553

Bowo, P. A. (2013). Kidpreneur is An Early Effort of Planting Entrepreneurship in Children to Embrace The Future. Indonesian Journal of Early Childhood Education Studies, 2(1), 5057. https://doi.org/10.15294/ijeces.v2i1.9220

Burcher, S. A., Serido, J., Danes, S., Rudi, J., \& Shim, S. (2018). Using The Expectancy-Value Theory to Understand Emerging Adults' Financial Behaviour and Financial WellBeing. Emerging Adulthood, 9(1), 66-75. doi.org/10.1177/2167696818815387.

Butterbaugh, S.M., Ross, D.B. \& Campbell, A. (2020). My Money and Me: Attaining Financial Independence in Emerging Adulthood through A Conceptual Model of Identity Capital Theory. Contemporary Family Therapy, 42, 33-45. doi.org/10.1007/ s10591-019-09515-8
Cacciattolo, K. (2015) Transition to adulthood. Research Gate. www.researchgate.net/publication/ 281108912_Transition_to_Adulthood

Carpenter, J. M., \& Moore, M. (2008). Gender and Credit Behaviors Among College Students: Implications for Consumer Educators. Journal of Family \& Consumer Sciences Education, 26 (1), 42-47. natefacs.org/ Pages/v26no1/v26n1Carpenter.pdf

Cuddy, A. J., Wolf, E. B., Glick, P., Crotty, S., Chong, J., \& Norton, M. I. (2015). Men As Cultural Ideals: Cultural Values Moderate Gender Stereotype Content. Journal of Personality and Social Psychology, 109(4), 622-635. https://doi.org/10.1037/pspi0000027

Fingerman, K. L., Cheng, Y., Wesselmann, E. D., Zarit, S., Furstenberg, F., \& Birditt, K. S. (2012). Helicopter Parents and Landing Pad Kids: Intense Parental Support of Grown Children. Journal of Marriage and Family, 74(4),880-896. doi.org/10.1111/j.1741-3737.2012. 00987.x

Fingerman, K. L., Kim, K., Davis, E. M., Furstenberg Jr, F. F., Birditt, K. S., \& Zarit, S. H. (2015). "I'll Give You The World": Parental Socioeconomic Background and Assistance to Young Adult Children. Journal of Marriage and Family, 77, 844-865. doi: 10.1111/jomf.12204

Frankenberg, E., Lillard, L., \& Willis, R. J. (2002). Patterns of Intergenerational Transfers in Southeast Asia. Journal of Marriage and Family, 64(3), 627-641. doi.org/10.1111/ j.1741-3737.2002.00627.x

Friedline, T., \& Rauktis, M. (2014). Young People are The Front Lines of Financial Inclusion: A Review of 45 Years of Research. Journal of Consumer Affairs, 48(3), 535-602. https://doi.org/10.1111/joca.12050

Harrison, T., Marchant, C., \& Ansell, J. (2016). Mind the Gap: Young Adult Financial Capability. Money Advice Service. masassets. blob.core.windows.net/cms/files/000/000/525/origi nal/2016_08_YA_Deep_Dive_Report_Final.pdf

Himawan, K. K., Bambling, M., \& Edirippulige, S. (2018). What does it Mean to Be Single in Indonesia? Religiosity, Social Stigma, and Marital Status among Never-Married Indonesian Adults. SAGE Open, 8(3). doi.org/10.1177/ 2158244018803132

Hurlock, E. B. (2017). Developmental Psychology: A Life-Span Approach. McGraw-Hill Education.

Johnson, M. K., \& Benson, J. (2012). The Implications of Family Context for The 
Transition to Adulthood. In Early adulthood in a family context (pp. 87-103). Springer.

Jones, G. (2010). Changing Marriage Patterns in Asia. SSRN Electronic Journal. doi.org/ 10.2139/ssrn.1716533

Kirkpatrick Johnson, M. (2013). Parental Financial Assistance and Young Adults' Relationships with Parents and Well-Being. Journal of Marriage and Family, 75(3), 713733. https://doi.org/10.1111/jomf.12029

Kusumawati, T., \& Kristiana, I. (2017). Usahaku, Pilihan Hatiku" Sebuah Studi Fenomenologi Tentang Makna Bekerja Pada Wanita Wirausahawan Batik Di Pekalongan. Empati, 6(1), 411-418.

Lai, M. S. (2011, January). Transition to Financial Independence of Youth in Asian Countries: Does Furthering One's Education Pay? | Nations UNIES. Welcome to the United Nations. www.un.org/development/desa/pd/fr/ node $/ 2559$

Lee, J. C., \& Mortimer, J. T. (2009). Family Socialization, Economic Self-Efficacy, and The Attainment of Financial Independence in Early Adulthood. Longitudinal and Life Course Studies, 1(1), 45-62. doi.org/10.1038/ Jid.2014.371

Lyons, A. C. (2004). A Profile of Financially AtRisk College Students. Journal of Consumer Affairs, 38(1), 56-80. doi.org/10.1111/j.17456606.2004.tb00465.x

Marsh, B. A. (2006). Examining The Personal Finance Attitudes, Behaviors, and Knowledge Levels of First-Year and Senior Students at Baptist Universities in The State of Texas (Bowling Green State University) [Doctoral dissertation].scholarworks.bgsu.edu/he_diss/8

Maholtra, N. (2019) Marketing Research: An Applied Orientation. 7th Ed. Upper Saddle River: Pearson:

Melgar, N., Mussio, I., \& Rossi, M. (2013). EconPapers: Environmental Concern and Behavior: Do Personal Attributes Matter? (113) Documentos de Trabajo (working papers) from Department of Economics dECON. econpapers.repec.org/paper/udewpaper/ 0113.htm

Melgar, N., \& Rossi, M. (2012). When do People Become Adults? The Uruguayan Case. International Journal of Population Research, 2012(1), 1-6. doi.org/10.1155/2012/425325

Minza, W. M. (2014). Growing Up and Being Young in an Indonesian Provincial Town [Doctoral dissertation]. www.uva.nl/binaries/ content/assets/uva/nl/onderzoek/promoveren/ samenvattingen/2014/05/samenvattingminza.pdf

Mortimer, J. T. (2012). The Evolution, Contributions, and Prospects of The Youth Development Study. Social Psychology Quarterly, 75(1), 5-27. doi.org/10.1177/01902725114349 11

Naafs, S. (2012). Youth, WorkaAnd Lifestyles in An Indonesian Industrial Town [Doctoral dissertation]. citeseerx.ist.psu.edu/viewdoc/ download?doi=10.1.1.846.3750\&rep=rep1\&t ype $=$ pdf

Newman, B. M., \& Newman, P. R. (2012). Development Through Life: A Psychosocial Approach. Cengage Learning.

Nobles, J., \& Buttenheim, A. (2008). Marriage and Socioeconomic Change in Contemporary Indonesia. Journal of Marriage and Family, 70 (4), 904-918. doi.org/10.1111/j.17413737.2008.00535.x

Oliveira, J. (2016). The Value of Children: Intergenerational Transfers, Fertility and Human Capital. Journal of Development Economics, 120, 1-16. doi.org/10.1016/j.jdeveco. 2015.12.002

Pappang, R. and Anastasia, N. (2019). The Impact of Perceived Financial Literacy and Parental Norm towards Money Management of Bidikmisi Student. International Journal of Business Studies, 3(2), 71-77, doi.org/10.9744 /ijbs.2.2.71-77

Sage, R. A., \& Johnson, M. K. (2012). Extending and Expanding Parenthood: Parental Support to Young Adult Children. Sociology Compass, 6(3), 256-270. https://doi.org/10.1111/j.17519020.2011.00446.x

Santrock, J. (2017). Lifespan Development. McGraw-Hill Education.

Schleicher, A. (2013). Key Findings from The 2013 OECD Survey of Adult Skills. AARP The Journal. journal-archive.aarpinternational.org/ a/b/2013/11/key-findings-from-the-2013oecd-survey-of-adult-skills

Shim, S., Barber, B. L., Card, N. A., Xiao, J. J., \& Serido, J. (2009). Financial Socialization of First-Year College Students: The Roles of Parents, Work, and Education. Journal of Youth and Adolescence, 39(12), 1457-1470.

Sironi, M., \& Furstenberg, F. F. (2012). Trends in the Economic Independence of Young Adults in the United States: 1973-2007. Population and Development Review, 38(4), 609-630. doi.org/10.1111/j.1728-4457.2012.00529.x

Smith, M. A., Baum, S., \& Mcpherson, M. S. (2008). Financial Independence and Age: Distributive Justice in The Case of Adult 
Education. Theory and Research in Education, 6(2), 131-152. doi.org/10.1177/1477878508091108

Swartz, T. T., Kim, M., Uno, M., Mortimer, J., \& O’Brien, K. B. (2011). Safety Nets and Scaffolds: Parental Support in The Transition to Adulthood. Journal of Marriage and Family, 73 (2), 414-429.

Tolles, J \& Meurer, W. J. (2016) Logistic Regression Relating Patient Characteristics to Outcomes. Journal of the American Medical
Association, 315(5), 533-534. doi:10.1001/ jama.2016.7653

Whittington, L. A., \& Elizabeth Peters, H. (1996). Economic Incentives for Financial and Residential Independence. Demography, 33(1), 8297. doi.org/10.2307/2061715

Xiao, J. J., Chatterjee, S., \& Kim, J. (2014). Factors Associated with Financial Independence of Young Adults. International Journal of Consumer Studies, 38(4), 394-403. 